\title{
UNIVERSITY FACULTY AND ADMINISTRATOR RESPONSES TO JOB STRAINS
}

\author{
Robert T. Blackburn, Stephen M. Horowitz, \\ Dee W. Edington, and Donald M. Klos
}

This study reports the relationships between job strain and several quality of life (QOL) indicators for a group of university faculty and administrators. The QOL indicators were in the domain of job satisfaction, life satisfaction, and health. Variables presumed to moderate the relationship between job strain and QOL were tested for their ability to buffer the strain effects. Analyses were carried out on faculty's and administrators' responses. The strong correlations obtained have both theoretical and practical consequences. Intervention strategies are discussed.

Both short-term and chronic stresses can result in various physiological, psychological, and behavioral strains which could ultimately translate into worker morbidity and premature mortality (Horowitz, 1983). French, Caplan, and Harrison (1982) believe that occupational stress is a prime factor in the pathogenesis of coronary heart disease (CHD). On a practical level, stress-related medical and health care costs to this nation may be over $\$ 200$ billion annually. It is in the best interests of employers to understand the effects of stress on lost workdays and health care costs, and to act accordingly to help employees learn to manage work-related stressors.

While faculty satisfaction is declining (Willie and Stecklein, 1982) and several experts believe stress in colleges and universities is increasing (see, e.g., Schuster and Bowen, 1985), there have only been a handful of empirical studies that link job-related strains to outcomes (Clark and Blackburn, 1973; Gmelch et al., 1983; Boberg and Blackburn, 1983). Further, only one study contains physiological measures (Brooks and Mueller, 1966). This

Robert T. Blackburn, Center for the Study of Higher and Postsecondary Education, University of Michigan, Ann Arbor, MI 48109. Stephen M. Horowitz, Department of Physical and Health Education, University of Texas at Austin; Dee W. Edington and Donald M. Klos, Division of Physical Education, University of Michigan.

\section{Research in Higher Education \\ (C) 1986 Agathon Press, Inc. \\ Vol. 25, No. 1}




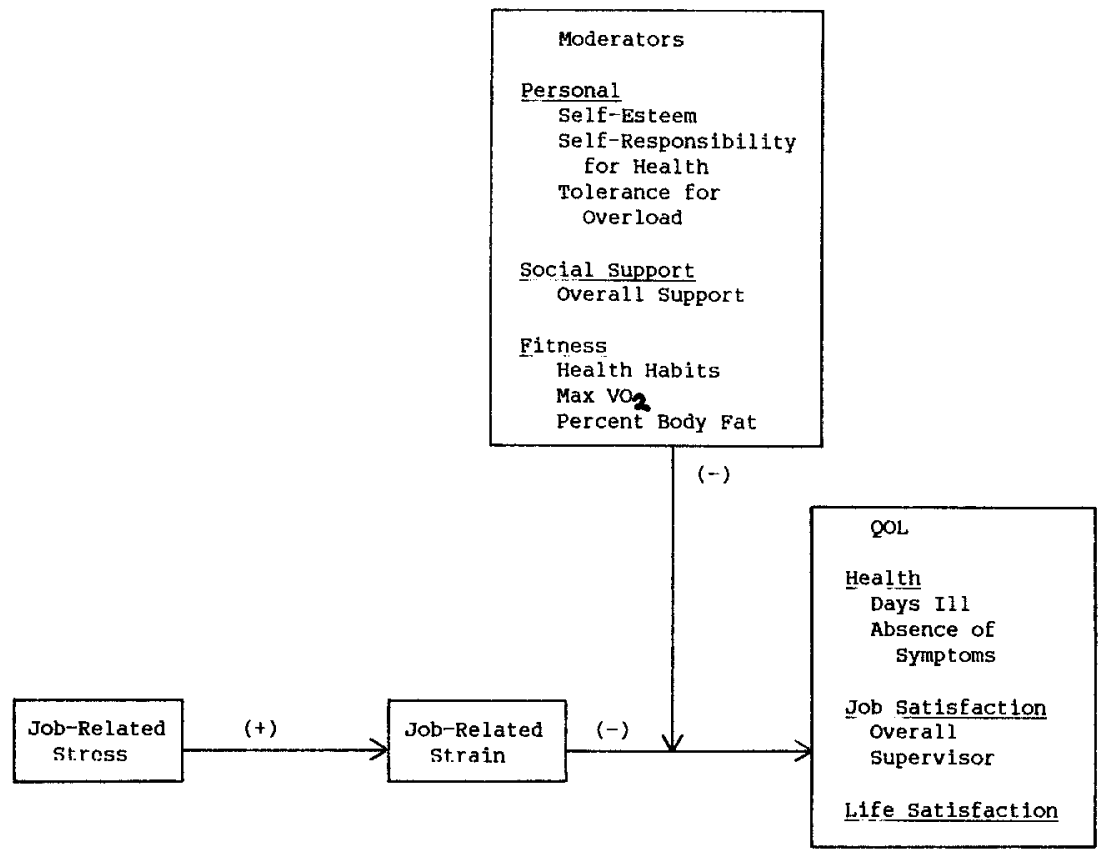

FIG. 1. Theoretical model describing the relationship between job stress, job strain, moderating variables, and quality of life (QOL) indicators.

study of the effects of job-related strains on the life, the job satisfaction, and the health of faculty and nonacademic administrators begins to fill this gap. It also explores how a number of variables moderate the effects of the job strains on the outcome measures.

\section{THEORETICAL FRAMEWORK}

Job strains in this paper will refer to job characteristics which the person perceives as discomforting, so that the person requires some type of psychological and/or physiological readjustment (Selye, 1974). Quality of life (QOL) indicators are defined as (1) satisfaction related to life; (2) satisfaction related to the job; and (3) health status, viz., experience of psychophysiological symptoms and days ill.

The model displayed in Figure 1 shows job strain (independent variable) and an array of presumed, associated consequences. Intervening are three types of moderating variables which are explored to assess the extent to which the QOL indicators associated with job strain might be modified. These particular variables were selected from a larger set because of their 
strong association with the principal measure of job strain. That is, their correlations suggest that the causal connection the model makes between job strain and various indicators of the quality of life would be buffered for individuals who more strongly held the appropriate moderating characteristics.

\section{DATA SOURCES}

The subjects were 57 nonacademic, high-level administrators and 46 faculty from humanities and natural science departments at the University of Michigan. All were males and most subjects were Caucasian (99\%). These groups were chosen because they represent two different types of work groups subjected to the same environmental pressures (since they are in the same organization). One (arts and science faculty) has appreciable control of time and type of work; the other (the nonacademic administrators) work in a bureaucracy with clear 9:00-5:00 schedules and for supervisors with authority. At the same time the groups are alike in terms of income and college education, two factors needing control since they correlate highly with health. The samples were further stratified by number of years at the university and indirect evidence of their physical activity. Random selection was then made within these defined populations. Table 1 displays the stress, moderator, and QOL characteristics of these groups.

\section{THE MEASURES AND METHODS}

Data were obtained from several different sources: the Lifestyle Analysis Questionnaire (LAQ), treadmill stress test, and underwater weighing. Additionally, each participant was asked to recall the number of days ill during the past three years.

The LAQ is a self-report instrument composed of a number of different tested and reliable instruments:

1. Clinical Affect Scale (Cobb, 1970)

2. Self-Esteem Scale (Coopersmith, 1959)

3. Problem Prevention (ISR)

4. Environmental Preference Scale (Haase, 1979)

5. Social Support Scale (LaRocco, House, and French, 1980)

6. Healthy Health Habits (Breslow and Enstrom, 1980)

7. Psychophysiological Symptoms (Langner, 1962)

8. Job-Descriptive Index (Locke, Smith, and Hulin, 1965)

9. Life Satisfaction Scale (Quinn and Staines, 1979) 
TABLE 1. Descriptive Data for University Faculty and Administrators

\begin{tabular}{|c|c|c|}
\hline Variable & $\begin{array}{c}\text { Faculty } \\
(N=47) \\
\text { Mean }( \pm S D)\end{array}$ & $\begin{array}{l}\text { Administrators } \\
\qquad(N=56) \\
\text { Mean }( \pm S D)\end{array}$ \\
\hline \multicolumn{3}{|l|}{ Stress } \\
\hline Job strain & $72.4 \quad(9.3)$ & $73.1(10.1)$ \\
\hline \multicolumn{3}{|l|}{ Moderators } \\
\hline Self-esteem & $84.1(10.8)$ & $85.2(11.8)$ \\
\hline Self-responsibility for health & $64.9 \quad(9.9)$ & $65.1(10.8)$ \\
\hline Tolerance for overload & $52.1 \quad(7.3)$ & $53.4 \quad(8.0)$ \\
\hline Overall social support & $66.3(8.8)$ & $65.4 \quad(9.6)$ \\
\hline Healthy habits & $64.3(13.8)$ & $59.4(15.0)$ \\
\hline $\operatorname{Max} \mathrm{VO}_{2}(\mathrm{ml} / \mathrm{kg} / \mathrm{min})$ & $38.9(5.8)^{a}$ & $36.4(6.4)^{a}$ \\
\hline Percentage body fat & $21.3(4.3)^{a}$ & $24.0(4.7)^{a}$ \\
\hline
\end{tabular}

QOL indicators

Days ill (past 3 years)

Absence of Symptoms

Life satisfaction

Overall job satisfaction

Satisfaction with supervisor

$\begin{array}{rrrr}6.9 & (9.7) & 8.7 & (10.6) \\ 88.0 & (6.2) & 92.4 & (6.8)^{b} \\ 81.0 & (9.1) & 79.4 & (9.9) \\ 64.4 & (6.3) & 64.1 & (6.9) \\ 69.0 & (6.3) & 68.4 & (6.2)\end{array}$

Note: Self-report scores (other than days ill) are relative measures and are a percentage of a total possible score. Higher scores indicate positive trends.

actual measurement.

${ }^{b} p<.05$, Student's $t$ test of mean difference.

The stress measure reported here is the Clinical Affect Scale developed at the Institute for Social Research at the University of Michigan. It consists of 16 items scored on a 5-point scale from "never" (1) to "most of the time" (5). Most of the items complete the sentence: "When you think about yourself and your job, how often do you feel. . .". Such nouns as "unhappy," "good," "nervous," and "cheerful" are presented.

Self-esteem is Coopersmith's Self-Esteem Scale, consisting of 17 items about oneself that the individual reports as true or false (e.g., I am proud of my work).

The self-responsibility for one's health variables is an 11-item scale on which subjects respond on a 6-point scale from "nothing" to "a great deal" indicating the amount that they can do to prevent various illnesses (heart attack, ulcers, etc.).

The tolerance variable is taken from Hasse's Environmental Preference 
Scale. Twenty-five items are responded to on a 5-point scale from "strongly agree" to "strongly disagree," and for the most part deal with one's ability to live with situations contrary to desires, e.g., maintaining a busy schedule, tolerating large crowds, and the like.

One social support moderator is used in the presented results. It combines four five-item scales on the amount of support (five levels) one receives from immediate family, close friends, coworkers, and one's supervisor (e.g., "the extent to which these people can be relied upon, no matter what"). These scales were developed at the Institute for Social Research at the University of Michigan.

Three fitness moderating variables are in the tables: healthy health habits, percentage. body fat, and maximum oxygen uptake. The 10-item scale, Healthy Health Habits, of which 7 items are from Breslow, is just that. On a 5-point scale from "almost always" to "never," respondents report their activities (e.g., have regular medical checkups, smoke cigarettes, etc.).

Health symptoms is the Langer 22-item Psychophysiological Symptoms Scale. On a 5-point scale from "always" to "never," one responds how often in the last 12 months he or she has had headaches, memory lapses, poor appetite, etc.

Job satisfaction is measured by the Job-Descriptive Index developed at Cornell. It consists of five subscales. All items are on a 5-point range from "always" to "never" for sets of words or phrases that deal with a person at work. One subscale is the people one works with (16 items such as stimulating, active). A second is the work itself (16 items such as boring, creative). The third deals with the supervision one receives (16 items such as tactful, bad). The fourth concerns promotion opportunities ( 9 items such as good, regular). The fifth deals with the pay received ( 8 items such as adequate, underpaid). The outcome measure titled "satisfaction with supervisor" is the third job satisfaction subscale just described.

Turning to the outcome variables, life satisfaction is a University of Michigan Institute for Social Research eight-item scale constructed in the form of a semantic differential. In responding to "how do you feel about your present life," 6-point scales are presented that range from boring to interesting, discouraging to hopeful, and the like.

Resting heart rate and blood pressures were determined for each subject prior to the administration of a graded exercise tolerance test. The treadmill protocol used was dependent upon the subject's reported activity level (American College of Sports Medicine, 1975). Subjects either exercised until at least $85 \%$ of predicted maximum heart rate was attained, until they were unable to continue due to fatigue, or when oxygen consumption plateaued with increasing work loads. 
TABLE 2. Pearson Product-Moment and Partial Correlations of Job Strain with Life Satisfaction, with and without Moderator Variable, by Personnel Type $(N=103)$

\begin{tabular}{|c|c|c|c|c|c|}
\hline \multirow{2}{*}{$\begin{array}{l}\text { QOL } \\
\text { Indicator }\end{array}$} & \multirow{2}{*}{ Selected Moderators } & \multicolumn{2}{|c|}{$\begin{array}{l}\text { Faculty } \\
(N=46)\end{array}$} & \multicolumn{2}{|c|}{$\begin{array}{l}\text { Administrators } \\
\qquad(N=57)\end{array}$} \\
\hline & & $\begin{array}{l}r \text { without } \\
\text { Moderator }\end{array}$ & $\begin{array}{c}r \text { with } \\
\text { Moderator }\end{array}$ & $\begin{array}{l}r \text { without } \\
\text { Moderator }\end{array}$ & $\begin{array}{c}r \text { with } \\
\text { Moderator }\end{array}$ \\
\hline \multirow{6}{*}{$\begin{array}{l}\text { Life } \\
\text { satisfaction }\end{array}$} & Tolerance for overload & $-.63^{a}$ & $-.49^{a}$ & $-.49^{\alpha}$ & $-.44^{a}$ \\
\hline & Self-esteem & $-.63^{a}$ & $-.44^{a}$ & $-.49^{a}$ & .08 \\
\hline & Overall social support & $-.63^{a}$ & $-.60^{a}$ & $-.49^{a}$ & $-.45^{a}$ \\
\hline & Healthy habits & $-.63^{a}$ & $-.61^{a}$ & $-.49^{a}$ & $-.50^{\alpha}$ \\
\hline & Percentage body fat & $-.63^{a}$ & $-.57^{a}$ & $-.49^{a}$ & $-.50^{a}$ \\
\hline & $\operatorname{Max} \mathrm{VO}_{2}(\mathrm{ml} / \mathrm{kg} / \mathrm{min})$ & $-.63^{a}$ & $-.71^{a}$ & $-.49^{a}$ & $-.47^{\alpha}$ \\
\hline
\end{tabular}

${ }^{a} p<.01$ for $t$ test of difference from zero.

The seated underwater weighing method was used for obtaining body density (Keys and Brozek, 1953). The Siri (1956) formula was utilized for estimating percentage body fat.

\section{STATISTICAL PROCEDURES}

Each variable was assumed to be measured on, at minimum, an ordinal scale, allowing Pearson product-moment correlations and regression statistics to be used. Intercorrelations among the stressors, the moderators, and the QOL indicators were obtained. Using QOL indicators as the dependent variables, stepwise multiple regression was performed to select the most appropriate moderating variables. Following this procedure, the selected moderating variables were partialled out of each job-stress-QOL-indicator correlation for each group (faculty and administrators) to examine their possible buffering effects. The $N$ s are too small for each group to carry out a full regression with job strain entered first. At the same time, to meet the objectives of the inquiry, the two groups were analyzed separately so as to learn if the consequences of strains on the job have different effects and if selected moderators will buffer the outcomes differently.

\section{RESULTS}

The sole significant difference between groups was for the self-reported measure, absence of psychophysiological symptoms, indicating the extent of emotional (e.g., nervousness) and physical (e.g., headaches) problems experienced within the last year (Table 1). With a score of 100 indicating no symptoms, administrators reported fewer stress-related problems than the faculty (92.2 vs. 88.6). 
TABLE 3. Pearson Product-Moment and Partial Correlations of Job Strain with Overall Job Satisfaction, with and without Moderator Variable, by Personnel Type $(N=103)$

\begin{tabular}{|c|c|c|c|c|c|}
\hline \multirow{2}{*}{$\begin{array}{l}\text { QOL } \\
\text { Indicator }\end{array}$} & \multirow{2}{*}{ Selected Moderators } & \multicolumn{2}{|c|}{$\begin{array}{l}\text { Faculty } \\
(N=46)\end{array}$} & \multicolumn{2}{|c|}{$\begin{array}{l}\text { Administrators } \\
\qquad(N=57)\end{array}$} \\
\hline & & $\begin{array}{l}r \text { without } \\
\text { Moderator }\end{array}$ & $\begin{array}{c}r \text { with } \\
\text { Moderator }\end{array}$ & $\begin{array}{l}r \text { without } \\
\text { Moderator }\end{array}$ & $\begin{array}{c}r \text { with } \\
\text { Moderator }\end{array}$ \\
\hline \multirow{6}{*}{$\begin{array}{l}\text { Overall } \\
\text { Job } \\
\text { satisfaction }\end{array}$} & Tolerance for overload & $-.48^{a}$ & $-.41^{a}$ & $-.61^{a}$ & $-.54^{a}$ \\
\hline & Self-esteem & $-.48^{a, c}$ & $-.11^{c}$ & $-.61^{a}$ & $.37^{b}$ \\
\hline & Overall social support & $-.48^{a}$ & $-.44^{a}$ & $-.61^{a}$ & $-.53^{a}$ \\
\hline & Healthy habits & $-.48^{a}$ & $-.44^{a}$ & $-.61^{a}$ & $-.63^{a}$ \\
\hline & Percentage body fat & $-.48^{a}$ & $-.43^{a}$ & $-.61^{a}$ & $-.61^{a}$ \\
\hline & $\operatorname{Max} \mathrm{VO}_{2}(\mathrm{ml} / \mathrm{kg} / \mathrm{min})$ & $-.48^{a}$ & $-.49^{a}$ & $-.61^{a}$ & $-.61^{a}$ \\
\hline
\end{tabular}

${ }^{a} p<.01$.

${ }^{b} p<.05$.

$c p<.03$, the difference between the two $r$ 's.

Tables 2-6 have identical formats with the QOL indicator in the first column and the moderating variables in the second. Pearson productmoment correlations are displayed for each group, both with and without moderator effects statistically removed.

Highly significant Pearson product-moment correlations $(p<.01)$ were found between administrator job stress and QOL indicators for job, life, and supervisor satisfaction, and symptoms. Self-reported number of days ill in the past three years was not significantly related to job strain.

Faculty had similar statistically significant relationships between job strain and QOL indicators except for supervisor satisfaction. From this finding, one might conclude that either faculty do not perceive that they have supervisors or else that their supervisors do not serve as a source of job stress. Additionally, faculty job strains were found to be positively associated with number of days ill (Table 6).

Some general observations from the figures are warranted. First, this one measure of job strain is significantly related to a number of QOL indicators.

Second, there are differences between faculty and administrators on a number of the variables. For the most part, for administrators, there is a significant association between job strain and their satisfaction with their supervisor. Such an association does not exist for faculty (Table 4). In addition, faculty appear to manifest job strain in the form of poorer life satisfaction, slightly higher stress-related symptomatology, and greater number of days ill. For faculty, work is life, and a low estimation of the professorial life is translated into a low quality of life as well.

Third, the moderators tended to reduce the magnitude of the direct correlations between the independent and each of the five dependent variables. 
TABLE 4. Pearson Product-Moment and Partial Correlations of Satisfaction with Supervisor with Job Strain, with and without Moderator Variable, by Personnel Type $(N=103)$

\begin{tabular}{|c|c|c|c|c|c|}
\hline \multirow{2}{*}{$\begin{array}{l}\text { QOL } \\
\text { Indicator }\end{array}$} & \multirow{2}{*}{ Selected Moderators } & \multicolumn{2}{|c|}{$\begin{array}{l}\text { Faculty } \\
(N=46)\end{array}$} & \multicolumn{2}{|c|}{$\begin{array}{l}\text { Administrators } \\
\qquad(N=57)\end{array}$} \\
\hline & & $\begin{array}{l}r \text { without } \\
\text { Moderator }\end{array}$ & $\begin{array}{c}r \text { with } \\
\text { Moderator }\end{array}$ & $\begin{array}{l}r \text { without } \\
\text { Moderator }\end{array}$ & $\begin{array}{c}r \text { with } \\
\text { Moderator }\end{array}$ \\
\hline \multirow{6}{*}{$\begin{array}{l}\text { Satisfaction } \\
\text { with } \\
\text { supervisor }\end{array}$} & Tolerance for overload & $-.15^{b}$ & -.14 & $-.58^{a, b}$ & $-.58^{a}$ \\
\hline & Self-esteem & -.15 & -.03 & $-.58^{a}$ & $.44^{a}$ \\
\hline & Overall social support & -.15 & -.14 & $-.58^{a}$ & $-.49^{a}$ \\
\hline & Healthy habits & -.15 & -.17 & $-.58^{a}$ & $-.58^{a}$ \\
\hline & Percentage body fat & -.15 & -.09 & $-.58^{\circ}$ & $-.58^{a}$ \\
\hline & $\operatorname{Max} \mathrm{VO}_{2}(\mathrm{ml} / \mathrm{kg} / \mathrm{min})$ & -.15 & -.07 & $-.58^{a}$ & $-.59^{a}$ \\
\hline
\end{tabular}

${ }^{a} p<.01$.

${ }^{b} p<.05$, the difference between faculty and administrator $r$ 's (without moderators).

(The $N$ size limited regression analysis and the combination of moderators. See the Horowitz, Blackburn, Edington, and Klos 1984 study, which demonstrates that combined moderators significantly reduced the correlations between job stress and three QOL indicators.) The effects of the moderators are discussed in the next section.

\section{DISCUSSION}

To begin with, the results lend support to the theoretical model which guided the inquiry. (See Figure 1.) However, direct measures of events causing reduction in QOL indicators are still needed. Also, it remains important to obtain outcome measures that are directly related to productivity for we still do not know the relationships between it and strains on the job. These two matters should be high on the research agenda.

What responsibility governing boards feel toward these strains and how they may be related to the effectiveness of their college or university is not known. One expects it to vary between individuals and institutions, and with the ever-changing personal and environmental situations. But supposing that the evidence leads to decisions to act, these findings provide some guidelines that may afford institutions with an avenue for improving and maintaining a higher quality of life for their employees.

To begin with, not only are some moderators more effective than others in mitigating the effects of strain on the QOL variables, but they differentially influence job strain-QOL relationships for faculty and administrators. Faculty with higher levels of self-esteem may be more capable of reducing strains which are manifested in the form of life satisfaction, job satisfaction (significantly so-see Table 3), symptoms, and days ill than are their col- 
TABLE 5. Pearson Product-Moment and Partial Correlations of Symptoms with Job Strain, with and without Moderator Variable, by Personnel Type $(N=103)$

\begin{tabular}{|c|c|c|c|c|c|}
\hline \multirow{2}{*}{$\begin{array}{l}\text { QOL } \\
\text { Indicator }\end{array}$} & \multirow{2}{*}{ Selected Moderators } & \multicolumn{2}{|c|}{$\begin{array}{l}\text { Faculty } \\
(N=46)\end{array}$} & \multicolumn{2}{|c|}{$\begin{array}{l}\text { Administrators } \\
\qquad(N=57)\end{array}$} \\
\hline & & $\begin{array}{l}r \text { without } \\
\text { Moderator }\end{array}$ & $\begin{array}{c}r \text { with } \\
\text { Moderator }\end{array}$ & $\begin{array}{l}r \text { without } \\
\text { Moderator }\end{array}$ & $\begin{array}{c}r \text { with } \\
\text { Moderator }\end{array}$ \\
\hline $\begin{array}{l}\text { Absence of } \\
\text { stress-related } \\
\text { symptoms }\end{array}$ & 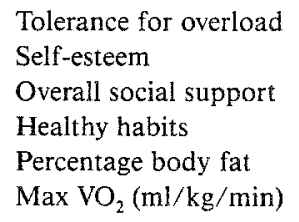 & $\begin{array}{l}-.65^{a} \\
-.65^{a} \\
-.65^{a} \\
-.65^{a} \\
-.65^{a} \\
-.65\end{array}$ & $\begin{array}{l}-.62^{a} \\
-.57^{a} \\
-.62^{a} \\
-.60^{a} \\
-.62^{a} \\
-.63^{a}\end{array}$ & $\begin{array}{l}-.62^{a} \\
-.62^{a} \\
-.62^{a} \\
-.62^{a} \\
-.62^{a} \\
-.62^{a}\end{array}$ & $\begin{array}{l}-.59^{a} \\
.56^{a} \\
-.62^{a} \\
-.60^{a} \\
-.62^{a} \\
-.63^{a}\end{array}$ \\
\hline
\end{tabular}

${ }^{a} p<.01$.

leagues who express lower levels of self-esteem. Raising a faculty member's tolerance for overload appears to moderate feelings of life dissatisfaction, while having a strong social support system and practicing more healthy habits may reduce number of days ill.

As with the faculty, administrators with higher levels of self-esteem tend to report fewer health problems and are more satisfied with their jobs and lives. Taking more responsibility for one's own health and having a strong support network may have additional beneficial effects on life satisfaction.

Moderators such as percentage body fat and maximum $\mathrm{VO}_{2}$ do not appear to mitigate job-strain-QOL relationships although physical fitness programs have been shown to have secondary benefits on self-esteem, job satisfaction, perceptions of job strains, and the practice of healthy habits (Heinzelmann, 1982; Chenoweth, 1981; Pauly, Palmer, and Wright, 1982). Colleges and universities could establish health promotion programs consisting of physical activity and stress management to improve these job-strain-related QOL indicators since they are likely to have experts already aboard and have facilities readily available. Setting up special aerobic exercise classes for faculty and administrators over the noon hours, as has been done at the University of Michigan, and making available complete treadmill stress tests for staff, as has been done at Hope College, are two specific examples.

While opportunities to improve employee quality of life are obviously needed, it should be realized that there is no simple and straightforward solution. The "productivity" of a university is a nebulous term, especially in comparison to a business organization. How a health promotion/stress reduction program will increase productivity will be comparatively more difficult to demonstrate in higher education than in profit-making organizations. By way of illustration, while relationships were found between job strain on the job and days ill, the actual number of days of work missed was 
TABLE 6. Pearson Product-Moment and Partial Correlations of Days Ill with Job Strain, with and without Moderator Variable, by Personnel Type $(N=103)$

\begin{tabular}{|c|c|c|c|c|c|}
\hline \multirow{2}{*}{$\begin{array}{l}\text { QOL } \\
\text { Indicator }\end{array}$} & \multirow{2}{*}{ Selected Moderators } & \multicolumn{2}{|c|}{$\begin{array}{l}\text { Faculty } \\
(N=46)\end{array}$} & \multicolumn{2}{|c|}{$\begin{array}{l}\text { Administrators } \\
\qquad(N=57)\end{array}$} \\
\hline & & $\begin{array}{l}r \text { without } \\
\text { Moderator }\end{array}$ & $\begin{array}{c}r \text { with } \\
\text { Moderator }\end{array}$ & $\begin{array}{l}r \text { without } \\
\text { Moderator }\end{array}$ & $\begin{array}{c}r \text { with } \\
\text { Moderator }\end{array}$ \\
\hline \multirow{6}{*}{ Days ill } & Tolerance for overload & $.38^{a}$ & $.33^{a}$ & .18 & .18 \\
\hline & Self-esteem & $.38^{\alpha}$ & .11 & .18 & .10 \\
\hline & Overall social support & $.38^{a}$ & .15 & .18 & .15 \\
\hline & Healthy habits & $.38^{a}$ & .12 & .18 & .15 \\
\hline & Percentage body fat & $.38^{a}$ & $.47^{a}$ & .18 & .09 \\
\hline & $\operatorname{Max} \mathrm{VO}_{2}(\mathrm{ml} / \mathrm{kg} / \mathrm{min})$ & $.38^{a}$ & $.45^{a}$ & .18 & .11 \\
\hline
\end{tabular}

${ }^{a} p<.01$.

very small. Unlike a business dependent upon an uninterrupted production line, or even an elementary and secondary school, which has an appreciable budget for substitute teachers, there is little cost to a college for a professor who is out for a day. A colleague takes over or the class is rescheduled. How much scholarly output is lost would be all but impossible to measure in quantitative or economic terms. In short, while we strongly advocate that colleges and universities set positive human resource goals which improve supervisory techniques, define job roles, improve fitness levels, and the like, they should know in advance that program effects may be very difficult to document.

Strains on the job will always exist, but there are many opportunities to lessen the potentially detrimental effects on quality of life. Taking positive actions to influence the work environment and improve employees' abilities to cope with job stress can help provide employees with healthier and more productive lives.

\section{REFERENCES}

American College of Sports Medicine. (1975). Guidelines for Graded Exercise Testing and Exercise Prescription. Philadelphia: Lea and Febiger.

Boberg, A. L., and Blackburn, R. T. (1983). Role stress, coping, and job-related strains in the academic workplace. Paper presented at annual AERA meeting, Montreal, April.

Breslow, L., and Enstrom, J. E. (1980). Persistence of healthy habits and their relationship to mortality. Preventive Medicine 9:469-483.

Brooks, G. W., and Mueller, E. F. (1966). Serum urate concentrations among university professors, relation to drive, achievement, and leadership. Journal of the American Medical Association 195(6): 415-418.

Chenoweth, D. (1981). Risk reduction strategies improve industrial complexion. Occupational Health \& Safety 50(4): 22-32. 
Clark, M. J., and Blackburn, R. T. (1973). Faculty performance under stress. In Alan L. Sockloff (Ed.), Faculty Effectiveness as Evaluated by Students (pp. 233-252). Philadelphia: Temple University.

Cobb, S. (1970). Class A variables from the card sort test (A study of people changing jobs, project analysis memo No. 12). Ann Arbor: University of Michigan, Institute of Social Research, July 24.

Coopersmith, S. (1959). A method for determining types of self-esteem. Journal of Abnormal Social Psychology 59: 87-94.

French, J. R. P., Jr., R. D. Caplan, and R. V. Harrison. (1982). The Mechanisms of Job Stress and Strain. New York: Wiley.

Gmelch, W. H., and others. (1983). Sources of stress in academe: A national perspective. Paper presented at the Annual Meeting of the American Educational Research Association, Montreal, Canada.

Haase, R. F. (1979). Polychronicity and strength of the nervous system as predictors of information overload. In A. G. Strelau and F. Farley (Eds.), Biological Basis of Personality and Activity. New York: Hemisphere.

Heinzelmann, F. (1972). Personal benefits of a health evaluation and enhancement program. NASA.

Horowitz, S. M., Blackburn, R. T., Edington, D. W., and Kloss, D. (1984). Some correlates of stress with life/job satisfaction in university faculty and administrators. Paper present at AERA annual meeting, New Orleans. 245-325.

Langner, T. S. (1962). A twenty-two item screening score of psychiatric symptoms indicating impairment. Journal of Health and Human Behavior 3: 269-276.

LaRocco, J. M., House, J. S., and French, J. R. P., Jr. (1980). Social support, occupational stress and health. Journal of Health and Human Behavior 21: 202-218.

Locke, E. A., Smith, P. C., and Hulin, C. L. (circa 1965). Cornell studies of job satisfaction: V scale characteristics of the Job Descriptive Index. Ithaca: Cornell University (mimeo).

Pauly, J. T., Palmer, J. A., and Wright, C. C. (1982). The effects of a 14-week employee fitness program on selected physiological and psychological parameters. Journal of Medicine 24(6): 457-463.

Quinn, R. P., and Staines, G. L. (1979). The 1977 Quality of Employment Survey. Ann Arbor: Institute for Social Research, University of Michigan.

Schuster, J. H., and Bowen, H. R. (1985). The faculty at risk. Change 17(4): 13-21.

Selye, H. Stress Without Distress. (1974). New York: J. P. Lippincott.

Siri, W. E. (1956). Gross composition of the body. In J. H. Lawrence and C. A. Tobias (Eds.), Advances in Biological and Medical Physics, Vol. 4. New York: Academic Press.

Willie, R., and Stecklein, J. E. (1982). A three decade comparison of college faculty characteristics, satisfactions, activities, and attitudes. Research in Higher Education 16: 81-93. 